\title{
AN ANALYSIS OF THE IN-SITU RESISTIVITY OF SEA ICE IN TERMS OF ITS MIGROSTRUGTURE
}

\author{
By G. W. Timco \\ (Division of Mechanical Engineering, National Research Council, Ottawa, Ontario K I A oR6, \\ Canada)
}

\begin{abstract}
The results of 66 Schlumberger geoelectric soundings on first-year sea ice are analysed to obtain average values of d.c. electrical resistivity both parallel $\rho_{1}$ and perpendicular $\rho_{\mathrm{p}}$ to the long brine cell direction. This analysis yields $\rho_{1}={ }_{10} \Omega \mathrm{m}, 80 \Omega \mathrm{m}, 45 \Omega \mathrm{m}$, and $\rho_{\mathrm{p}}=298 \Omega \mathrm{m}, 230 \Omega \mathrm{m}, 129 \Omega \mathrm{m}$ for brine volumes $v_{\mathrm{b}}$ of $40 \%, 67 \%$, and $82 \%$ respectively. The observed dependence of $\rho_{1}$ on $v_{\mathrm{b}}$ is used in conjunction with a mixing formula for the electrical resistivity of a two-phase heterogeneous system to arrive at values of "average" brine cell lengths $l$ for relatively warm sea ice. This treatment yields $l \approx 1.7 \mathrm{~cm}$ for $40 \% \leqslant v_{\mathrm{b}} \leqslant 70 \%$ with a rapid extension of brine cell lengths for brine volumes above $c .70 \%$.

RÉsumé. Une analyse de la résistivité in situ de la glace de mer en fonction de sa microstructure. Les résultats de sondages géoélectriques Schlumberger sur de la glace de mer de première année sont analysés pour obtention des valeurs de la résistivité électrique d.c. dans les directions parallèles $\rho_{1}$ et perpendiculaire $\rho_{\mathrm{p}}$ aux inclusions allongées de saumure. Cette analyse donne $\rho_{1}=104 \Omega \mathrm{m}, 80 \Omega \mathrm{m}, 45 \Omega \mathrm{m}$ et $\rho_{\mathrm{p}}=298 \Omega \mathrm{m}, 230 \Omega \mathrm{m}$, ${ }_{129} \Omega \mathrm{m}$ respectivement pour des volumes de saumures $v_{\mathrm{b}}$ de $40 \%, 67 \%$ et $82 \%$. On utilise la relation observée entre $\rho_{1}$ et $v_{\mathrm{b}}$ en conjonction avec une formule de mélange pour la résistivité électrique d'un système hétérogène à deux phases pour parvenir à des valeurs des longueurs "moyennes" $l$ des inclusions de saumure pour de la glace de mer relativement chaude. Ce traitement aboutit à une longueur $l \approx 1,7 \mathrm{~cm}$ pour $40 \% \leqslant$ $v_{\mathrm{b}} \leqslant 70 \%$ avec une rapide croissance de la longueur des inclusions pour des volumes de saumure supérieurs à environ $70 \%$.

Zusammenfassung. Eine Analyse des in-situ-Widerstands von Meereis in Abhängigkeit von seiner Mikrostruktur. Die Ergebnisse der geoelektrischen Dickenmessungen Schlumbergers an einjährigem Meereis werden analysiert mit dem Ziel, Werte für den Gleichstromwiderstand sowohl parallel $\rho_{1}$ wie senkrecht $\rho_{\mathrm{p}}$ zur Längsrichtung der Salzwasserzellen zu erhalten. Diese Analyse liefert Werte von $\rho_{1}=104 \Omega \mathrm{m}, 80 \Omega \mathrm{m}$, $45 \Omega \mathrm{m}$ und $\rho_{\mathrm{p}}=298 \Omega \mathrm{m}, 230 \Omega \mathrm{m}$, I $29 \Omega \mathrm{m}$ für entsprechende Solevolumina $v_{\mathrm{b}}$ von $40 \%, 67 \%$ und $82 \%$. Die beobachtete Abhängigkeit zwischen $\rho_{1}$ und $v_{\mathrm{b}}$ wird in Verbindung mit einer Mischformel für den elektrischen Widerstand eines heterogenen Zwei-Phasen-Systems zur Gewinnung von Werten einer "mittleren" Länge $l$ der Salzwasserzellen in relativ warmen Meereis herangezogen. Dieses Vorgehen liefert $l \approx 1,7 \mathrm{~cm}$ für $40 \% \leqslant v_{\mathrm{b}} \leqslant 70 \%$ wobei die Länge der Salzwasserzellen für Solevolumina von mehr als $70 \%$ sehr schnell ansteigt.
\end{abstract}

\section{INTRODUCTION}

The d.c. resistivity of sea ice is influenced by many factors including the salinity, temperature, and age of the ice as well as the size, distribution, and geometry of the brine cells. Basically, the d.c. resistivity of sea ice may be studied either by standard d.c. measurements of small ice samples obtained from cores cut from the ice sheet, or by geoelectric sounding techniques. The former method has the advantage that the electric field direction is well defined with respect to the geometry of the brine cells. However, it has the disadvantage that significant brine drainage can occur before the measurement can be performed, and this leads to erroneous results. The latter technique of geoelectric sounding overcomes this problem since the resistivity is measured as a function of the electrode spacing (i.e. the depth of penetration) and therefore the ice is measured in situ. Unfortunately, however, due to the complex nature of sea ice, interpretation difficulties usually hamper the amount of information which can be derived from the geoelectric sounding results. With investigations of this kind, one obtains values for both apparent resistivity and apparent ice thickness. In this note, we extend the usual interpretation of geoelectric sounding results on sea ice to obtain values of in-situ resistivity for directions both parallel and perpendicular to the brine cells of the sea-ice strata. In addition, using a general conductivity mixing formula in conjunction with the results obtained for the resistivity parallel to the brine cells, we calculate values of "average" brine cell lengths for relatively warm sea ice. 
Field Results: Pond Inlet, N.W.T.

The present work is based on the results of a series of Schlumberger geoelectric soundings performed on first-year sea ice near Pond Inlet, N.W.T. in the spring of 1972 (Cowan and others, unpublished; Thyssen and others, I974; Kohnen, [1976]). In soundings of this kind, a current is introduced into the ground by two electrodes, and using non-polarizable electrodes, the potential difference is measured between two points centred about the mid-point of the line connecting the current electrodes. The outer electrodes are then expanded about the mid-point to obtain greater depth of penetration into the ice. The measured resistivity $\rho$ is then determined by

$$
\rho=\frac{\pi}{4} \frac{V}{I} \frac{L^{2}-d^{2}}{d}
$$

where $V$ is the potential difference, $I$ is the current, $L$ is the current-electrode spacing, and $d$ is the voltage-electrode spacing. The measured resistivity is plotted against $L / 2$ on $\log -\log$ paper to evaluate the resistivity and thickness of the ice cover.

Twenty-two soundings were made spaced at $\mathrm{I} \mathrm{km}$ intervals across first year ice from Pond Inlet on northern Baffin Island to a southern point on Bylot Island. These soundings were repeated at intervals of $c .2$ weeks ( $16-19$ May, 3-6 June, and I $5^{-21}$ June) in order to obtain information on the change in resistivity with time (i.e. temperature). In addition, on 8 June (i.e. immediately after the 3-6 June traverse), a pit $c$. I $\mathrm{m}$ deep was dug into the unrafted ice to measure the apparent resistivity perpendicular to the top surface of the ice.

TABLE I. RESUltS OF GEOELECTRIC SOUNDINGS ON RELATIVELY WARM ice AT Pond Inlet, N.W.T.

\begin{abstract}
$\rho_{\mathrm{u}}$ is the resistivity of upper layer (top $\frac{1}{4}$ of ice sheet), $\rho_{\mathrm{a}}$ the resistivity of lower layer (bottom $\frac{3}{4}$ of ice sheet). The temperature $T$ and brine volume $v_{\mathrm{b}}$ which correspond to the lower layer were measured in unrafted ice at a position $c . \frac{1}{3}$ the way across the Inlet (after Thyssen and others, 1974).
\end{abstract}

$\begin{array}{cccccc}\text { Traverse } & \text { Date } & \rho_{\mathrm{u}} & \rho_{\mathrm{a}} & T & v_{\mathrm{b}} \\ & & \Omega \mathrm{m} & \Omega \mathrm{m} & { }^{\circ} \mathrm{C} & \% \\ \text { I } & \text { 16-19 May } & \text { 1 12 } & \text { 1 } 76 & -6.5 & 40 \\ 2 & \text { 3- 6 June } & 46 & 136 & -3.7 & 67 \\ 3 & \text { 15-2 I June } & 30 & 76 & -3.0 & 82\end{array}$

Interpretation of the results indicated that the ice could be considered as a two-layer case: (I) a low resistivity $\rho_{\mathrm{u}}$ layer for the upper $c$. $\frac{1}{4}$ of the ice sheet; and (2) a higher resistivity $\rho_{\mathrm{a}}$ layer for the lower $c . \frac{3}{4}$ of the ice sheet (Thyssen and others, I974; Kohnen, [1976]). The values for these layers averaged over the 22 soundings for each traverse are listed in Table I. In addition, both the average temperature $T$ and brine volume $v_{\mathrm{b}}$ of the lower ice layer are listed in this table. The latter was calculated from (Frankenstein and Garner, 1967)

$$
v_{\mathrm{b}}=S\left[\frac{45.9 \mathrm{I} 7}{|T|}+0.93^{\circ}\right]
$$

where the salinity $S$ of the ice at Pond Inlet was measured to be $c .5 \%$ relatively independent of depth in the lower layer (Kohnen, [1976]). For the resistivity measurement perpendicular to the ice surface, twenty measurements yielded $\rho_{\mathrm{v}} \approx 229 \Omega \mathrm{m}$ (Cowan and others, unpublished). For more details regarding the experimental aspects and general results of this investigation, including a general discussion on the factors influencing the resistivity of sea ice, the reader is referred to the articles by Thyssen and others (1974) and Kohnen ([1976]). 


\section{Migrostritigture of SEA IGE}

When sea-water freezes, the resulting ice sheet shows distinct features which are characteristic of solids grown from impure melts. In the upper surface layer of the sheet, a large number of the ice crystals grow with their c-axis aligned vertically. However, as the sheet thickens, a process of geometric selection takes place whereby crystals with favoured orientations eliminate those in other orientations by cutting them off from the melt. This results from the fact that the growth-rate is more rapid along the (ooor) basal plane than in the direction perpendicular to it (Hillig, 1958). This anisotropic growth-rate has the net effect that with increasing depth, the orientations of the $c$-axes of the crystals change from being predominantly vertical to predominantly horizontal, such that from a depth of $c$. $40 \mathrm{~cm}$ to the bottom of the ice sheet, the $c$-axes are strictly horizontal. During growth, liquid brine is trapped and contained in thread-like pockets or cells which are aligned in very thin layers parallel to the (ooo I) basal plane (i.e. perpendicular to the $c$-axis), and at intercrystalline boundaries. These

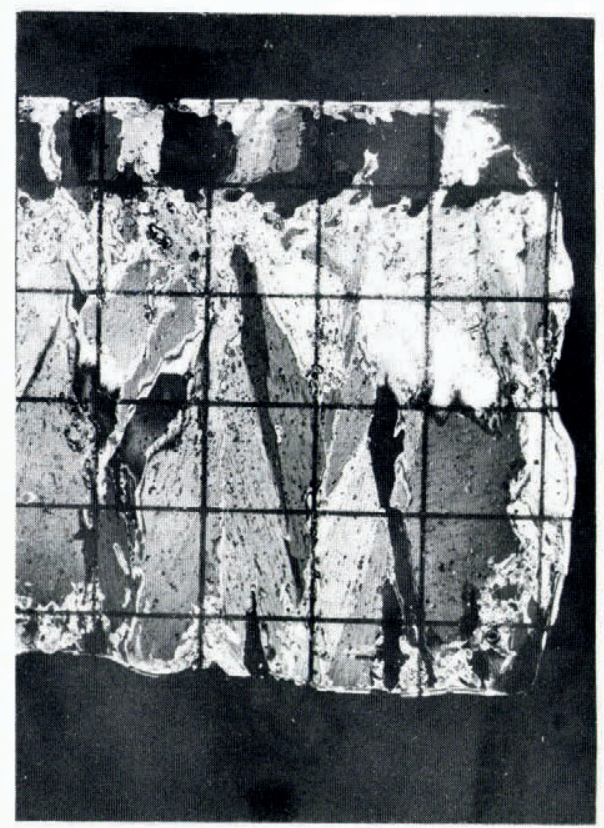

Fig. I. Photomicrograph of a vertical cross-section of a thin sheet of $\mathrm{NaCl}$ ice showing both the laminar microstructure of the thread-like brine cells and the air pockets. The grid is $\mathrm{I} \mathrm{cm}$ on a side.

brine inclusions within the ice crystals produce a pronounced substructure which is readily observable in thin sections (Fig. I). In general, the size and shape of the thread-like brine pockets are a complex function of the ice salinity and temperature. For sea ice, the concentration of the brine in the ice is determined by the phase diagram of salts and water, which because of the many kinds of salt present is quite complex (Assur, I 958). With changes in temperature, the liquid inclusions change size. If the ice cools, some water freezes out of the brine pockets. This decreases the size of the brine cells and increases the salt concentration in the cells to the equilibrium value. If the ice warms, the brine will dissolve some ice, thereby increasing the volume of the cell. At the higher ice temperatures close to melting, this increase in volume often leads to an interconnection of the brine pockets in the vertical direction. Typical diameters of these brine cells are on the order of $0.05 \mathrm{~mm}$ (Anderson, i 960 ; Pounder, [ $\left.{ }^{\mathrm{c}}{ }_{1965}{ }^{6}\right]$ ). 
The lengths of the brine cells are much more variable than the diameters, and are not well known. Quoted values for the brine cell lengths of relatively warm ice are typically on the order of $2-3 \mathrm{~cm}$ (Pounder, I965; Addison, I969).

\section{ANISOTROPY OF SEA IGE IN THE LOWER LAYER}

From the foregoing discussion it is evident that the lower layer of sea ice may be treated as a relatively pure ice matrix enclosing long, thin, spheroidal or cylindrical-shaped pockets of brine which are all aligned in the vertical direction. Since the ice matrix has a resistivity much higher than that of the brine inclusions, the resistivity in this layer would be highly anisotropic. Clearly, the resistivity of this layer would be dependent upon the direction of the current relative to the brine cells, such that the resistivity in the vertical direction would be much lower than the resistivity in any horizontal direction. At this stage, for a proper analysis of the resistivity data, we must examine the nature of the ice studied to determine if, on a macroscopic scale, the resistivity would be the same in any horizontal direction; i.e. to determine if there is a preferred horizontal alignment of the $c$-axes of the ice crystals in the lower layer. Recently, for example, Campbell and Orange (1974) have found evidence of horizontal electrical anisotropy in sea ice off the Canadian Arctic Islands, and Gow and Weeks (1977) have found strongly-preferred crystal orientation in the lower layer of sea ice near Narwhal Island in the Beaufort Sea. To check for the possible existence of horizontal electrical anisotropy in the present case of the Pond Inlet ice, two independent Schlumberger profiles were performed at each station such that the profiles were perpendicular to one another but centred at the same mid-point. This was done at each of the first eight stations on the 16 -ig May traverse. With this technique, one samples essentially the same volume of ice at each station, but from two different (perpendicular) directions. If a strong alignment of $c$-axis orientation in the horizontal plane exists in the ice, then a large discrepancy would be found between the two apparent resistivity values. This was not found to be the case. The average difference between the two resistivity values was on the order of $5 \%$, which was within the experimental accuracy of the tests.

For the Pond Inlet ice considered in this analysis, we therefore have the case of transverse isotropy, i.e. resistivity independent of direction in the horizontal plane but different perpendicular to the plane. Situations similar to this are frequently encountered in geophysical prospecting with the difference that in mineral prospecting, the resistivity along the stratified layer is usually less than the resistivity perpendicular to it. In spite of this difference, we can still apply the general formulation for this situation as discussed by Bhattacharya and Patra (I968). In the case of microscopic anisotropy, the measured (apparent) resistivity $\rho_{\mathrm{a}}$ determined using the Schlumberger configuration is given by

$$
\rho_{\mathrm{a}}=\frac{\rho_{\mathrm{m}}}{\left\{\mathrm{I}+\left(\lambda^{2}-\mathrm{I}\right) \sin ^{2} \phi \sin ^{2} \alpha\right\}^{\frac{1}{2}}},
$$

where, as shown in Figure 2, $\alpha$ is the dip angle of the electrically isotropic (EI) planes from the horizontal, $\phi$ is the angle made by the point of observation and the strike direction of the EI planes, $\lambda$ is the coefficient of anisotropy, and $\rho_{\mathrm{m}}$ is the mean resistivity.

Defining $\rho_{\mathrm{p}}$ as the resistivity parallel to the electrically isotropic planes (i.e. the horizontal resistivity), and $\rho_{1}$ as the resistivity along the anisotropic direction (i.e. the vertical resistivity which is parallel to the long direction of the brine cells), $\lambda$ and $\rho_{\mathrm{m}}$ are given by

$$
\begin{aligned}
\lambda & =\sqrt{ }\left(\rho_{\mathrm{l}} / \rho_{\mathrm{p}}\right), \\
\rho_{\mathrm{m}} & =\sqrt{ }\left(\rho_{\mathrm{p}} \rho_{\mathrm{l}}\right) .
\end{aligned}
$$

For the Schlumberger measurements on the surface of the ice, $\alpha=0$ and thus the resistivities are all measures of the mean resistivity, i.e.

$$
\rho_{\mathrm{a}}=\rho_{\mathrm{m}}=\sqrt{ }\left(\rho_{\mathrm{p}} \rho_{\mathrm{l}}\right) .
$$






Fig. 2. Geometry for Equation (3) showing the air-ice surface and a vertical section through the ice: $X^{\prime} Y^{\prime}$ is air-ice boundary surface; $X Y$ is electrically isotropic (EI) planes; $\alpha$ is dip of EI planes from horizontal; $\phi$ is angle made by point of observation and the strike direction of the EI planes.

However, for the experiment on the wall in the ice pit, with the array of electrodes vertical, $\alpha=\pi / 2$ and $\phi=\pi / 2$, and the apparent resistivity measured in the vertical direction on the wall is (from Equation (3))

$$
\rho_{\mathrm{v}}=\frac{\rho_{\mathrm{m}}}{\left\{\mathrm{I}+\left(\lambda^{2}-\mathrm{I}\right) \times \mathrm{I} \times \mathrm{I}\right\}^{\frac{1}{2}}}=\frac{\rho_{\mathrm{m}}}{\lambda}=\rho_{\mathrm{p}} .
$$

Thus, from Equations (4) and (5), and using $\rho_{\mathrm{m}}=\mathrm{r} 36 \Omega \mathrm{m}$ (i.e. the mean resistivity of the lower layer for the second traverse, Table I), and $\rho_{\mathrm{v}}=\rho_{\mathrm{p}}=229 \Omega \mathrm{m}$ (Cowan and others, unpublished), we get $\lambda=0.59$ for this ice. This value of $\lambda$ for the ice on all three traverses and the value for the average mean resistivity $\rho_{\mathrm{m}}$ for each traverse (Table I) can then be used to get the resistivity parallel to the brine strata $\rho_{1}$ and the resistivity perpendicular to the brine strata $\rho_{\mathrm{p}}$ from Equations (4) and (5). These values are listed along with the temperature and brine volume of this layer in Table II. Note that the resistivity decreases with increasing temperature and brine volume. This is a reflection of the changes in size and geometry of the brine cells with temperature. This suggests that by applying a suitable mixing formula, it should be possible to obtain some general information on the dependence on temperature and brine volume of the size and geometry of "average" brine cells in sea ice.

TABLE II. In-situ RESISTIVITY RESULTS FOR THE LOWER LAYER

$\rho_{\mathrm{m}}$ is the mean resistivity, $\rho_{1}$ the resistivity parallel to the brine cells, $\rho_{p}$ the resistivity perpendicular to the brine cells.

$\begin{array}{cccccc}\text { Traverse } & \rho_{\mathrm{m}} & \rho_{\mathrm{l}} & \rho_{\mathrm{p}} & T & v_{\mathrm{b}} \\ & \Omega \mathrm{m} & \Omega \mathrm{m} & \Omega_{\mathrm{m}} & { }^{\circ} \mathrm{C} & \% \\ \mathrm{I} & 176 & 104 & 298 & -6.5 & 40 \\ 2 & 136 & 80 & 230 & -3.7 & 67 \\ 3 & 76 & 45 & 129 & -3.0 & 82\end{array}$

\section{CONDUGTIVITY MODEL: SYSTEMS CONTAINING DISPERSED SPHEROIDS}

In choosing a way to describe the electrical properties of sea ice, it is clear that due to the nature and complexity of sea ice, several approximations and simplifications must necessarily be made. Ideally, we would like to use a model which treats the electrical resistivity using 
some prescribed form of statistical distributions for the brine-cell lengths, widths, and spatial distribution. Unfortunately, due to the lack of such a theory as well as insufficient information on the physical properties of brine cells, this is not yet possible. In the past, however, there have been several theories which have been used successfully to calculate the apparent resistivity of a two-phase heterogeneous system. These are based on the premise of constant size and shape of the inclusions, and the assumption that the heterogeneous system can be represented electrically by an equivalent network consisting of linear elements. Several such treatments date back to the times of Maxwell, Poisson, and Lord Rayleigh. For the present case of sea ice which may be regarded as a mosaic of brine pockets in an ice matrix, we choose as a model that of conducting spheroids in a poorly-conducting matrix (Fig. 3). Clearly, such a model is very highly idealized and should not be interpreted as a rigorous representation of sea-ice structure. Nevertheless, it is felt that such an approach does provide useful information with regard to the typical characteristics of brine cells in sea ice. Similar treatments have been used successfully to describe both the mechanical properties of sea ice (Assur, I958; Weeks and Assur, 1963, 1968) and the thermal conductivity (Anderson, 1958), and to estimate the electrical relaxation time of an ice-brine mixture (Hoekstra and Cappillino, 1971).

Following Fricke (1924) and Beek ( 1967$)$, the resistivity $\rho$ of a system of the type shown in Figure 3 is given by

$$
\frac{\mathrm{I}}{\rho}=\frac{\sigma_{\mathrm{i}}\left\{\sigma_{\mathrm{i}}+\left[A_{\mathrm{a}}\left(\mathrm{I}-\mathrm{I} \mathrm{O}^{-3} v_{\mathrm{b}}\right)+\mathrm{I} \mathrm{O}^{-3} v_{\mathrm{b}}\right]\left(\sigma_{\mathrm{b}}-\sigma_{\mathrm{i}}\right)\right\}}{\sigma_{\mathrm{i}}+A_{\mathrm{a}}\left(\mathrm{I}-\mathrm{I} \mathrm{O}^{-3} v_{\mathrm{b}}\right)\left(\sigma_{\mathrm{b}}-\sigma_{\mathrm{i}}\right)},
$$

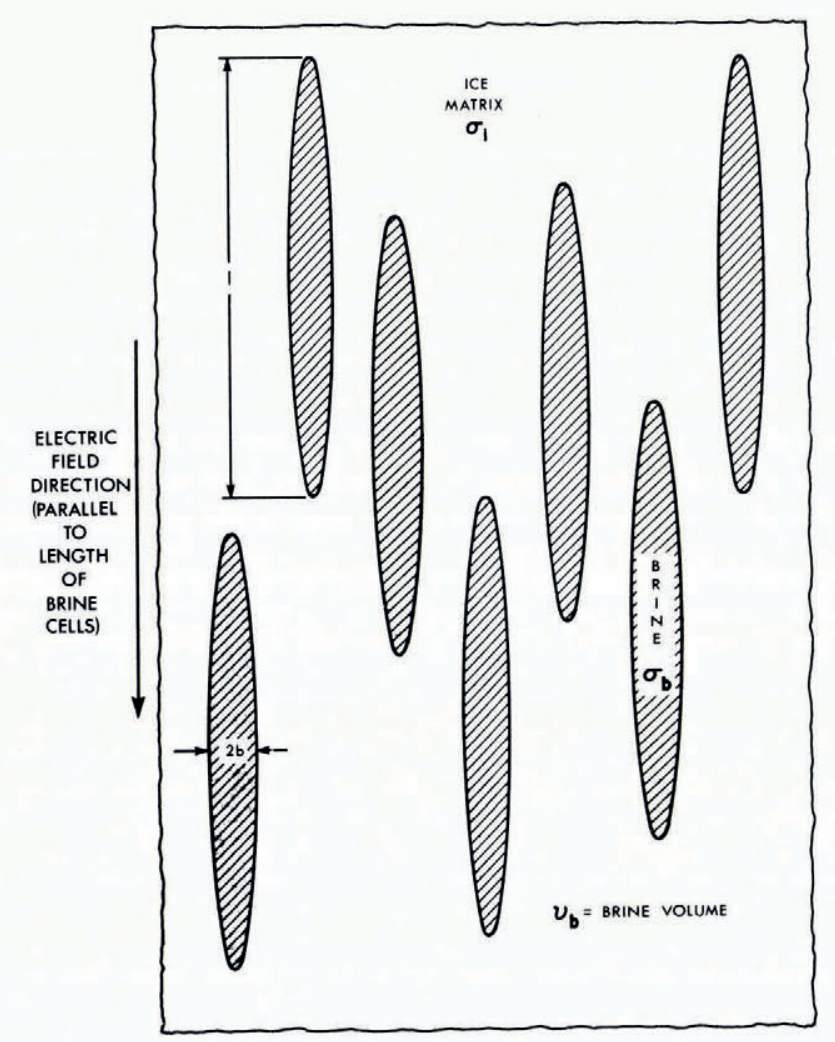

Fig. 3. Schematic cross-sectional representation of the prolate spheroid conductivity model of brine cells for Equations $(8)$ and $(9)$. 
where for the present case $\sigma_{\mathrm{i}}$ is the conductivity of the ice matrix, $\sigma_{\mathrm{b}}$ is the conductivity of the brine inclusions, and $v_{\mathrm{b}}$ is the brine volume in parts per thousand. The depolarization factor $A_{\mathrm{a}}$ for the case of prolate spheroids (with the field parallel to the long axis of the spheroid) is

$$
A_{\mathrm{a}}=\frac{-\mathrm{I}}{(l / 2 b)^{2}-\mathrm{I}}+\frac{(l / 2 b)}{\left[(l / 2 b)^{2}-\mathrm{I}\right]^{\frac{3}{2}}} \ln \left\{\left(\frac{l}{2 b}\right)+\left[\left(\frac{l}{2 b}\right)^{2}-\mathrm{I}\right]^{\frac{1}{2}}\right\},
$$

where $b$ is the radius of an average brine cell and $l$ is the length of a brine cell. Thus, the resistivity of such a two-phase heterogeneous system depends upon the electrical conductivity of the matrix and inclusions, and both the relative amount and axial-ratio (geometry and size) of the inclusions. In the present case, we can greatly simplify Equations (8) and (9) since $\sigma_{\mathrm{b}} \gg \sigma_{\mathrm{i}}, \mathrm{IO}^{-3} v_{\mathrm{b}} \approx 0.05$ and $l \gg b$ (i.e. $A_{\mathrm{a}} \ll \mathrm{I}$ ). Thus, Equation (8) becomes

$$
\rho_{1} \simeq \frac{\sigma_{\mathrm{i}}+A_{\mathrm{a}}\left(\mathrm{I}-1 \mathrm{I}^{-3} v_{\mathrm{b}}\right) \sigma_{\mathrm{b}}}{1 \mathrm{O}^{-3} v_{\mathrm{b}} \sigma_{\mathrm{i}} \sigma_{\mathrm{b}}}
$$

and Equation (9) becomes (after Beek, 1967)

$$
A_{\mathrm{a}} \simeq[\ln (l / b)-\mathrm{I}](2 b / l)^{2} .
$$

For sea ice, we can make reasonable estimates for the brine volume as well as the conductivity of both the ice matrix and the brine cells. Moreover, typical values of the radii of brine cells in sea ice have been determined petrologically. Thus, using the values of the in-situ resistivity for the direction parallel to the brine cells $\rho_{1}$, we can use this formulation to calculate values of brine cell lengths for the model.

\section{Application using average values for sea ice}

To apply this to the present case, we first choose overall average values for $\rho_{1}$ and $v_{\mathrm{b}}$ from the 66 Schlumberger soundings in order to check the general applicability of these equations for sea ice. From Table II, $\bar{\rho}_{1} \approx 76 \Omega \mathrm{m}$ and $\bar{v}_{\mathrm{b}} \approx 63 \%$. To obtain a value for the conductivity of the ice matrix, we note that the matrix is itself not pure ice since it contains small amounts of solid salts, impurities, and trapped air. As such, a representative value for $\sigma_{i}$ would be obtained by measurement of either low-salinity sea ice or very cold sea ice. Independent measurements on both warm, low-salinity sea ice (Pounder and Little, 1959) and on very cold sea ice measured perpendicular to the long axis of the brine cells (Dichtel and Lundquist, I95 I) yield d.c. conductivity values of $3 \times \mathrm{IO}^{-5} \mathrm{~S} / \mathrm{m}$; hence $\sigma_{\mathrm{i}}=3 \times \mathrm{IO}^{-5} \mathrm{~S} / \mathrm{m}$. To obtain a value for $\sigma_{\mathrm{b}}$, we know that from the salinity $(5 \%)$ and brine volume $(c .63 \%)$ of the Pond Inlet ice, the concentration of salt in the brine pockets is on the order of $80 \mathrm{~g} / \mathrm{l}$. For electrolytic solutions of this concentration, the conductivity $\sigma_{\mathrm{b}}$ is $c .5 \mathrm{~S} / \mathrm{m}$ (Keller and Frischknecht, I 966 ). Since the dimensions and spacing of the brine cells vary considerably, they must be analysed statistically. This has been done by petrological studies for both the spacing and width of the ice platelets, and also for the radius of the brine cells (Anderson, r 96o; Weeks and Hamilton, I 962). For sea ice of brine volume $63 \%$, typical brine-cell radii are $b \approx 0.046 \mathrm{~mm}$ (Anderson, I96o). Then using Equations (Io) and (I I) with $\bar{\rho}_{1}=76 \Omega \mathrm{m}, v_{\mathrm{b}}=63 \%{ }_{0}, \sigma_{\mathrm{i}}=3 \times \mathrm{Io}^{-5} \mathrm{~S} / \mathrm{m}$, $\sigma_{\mathrm{b}}=5 \mathrm{~S} / \mathrm{m}$, and $b=0.046 \mathrm{~mm}$, we get $\bar{l} \approx \mathrm{r} .7 \mathrm{~cm}$. This says that, from the electrical point of view, the value of the electrical resistivity of sea ice parallel to the brine-cell direction would be the same as that measured experimentally if the ice consisted of brine cells of $1.7 \mathrm{~cm}$ length and $0.046 \mathrm{~mm}$ radius and brine volume of $63 \%$; that is, electrically they are equivalent. Thus, in a manner similar to taking a statistical value for $b$, we can call $\bar{l}$ the "average" brine cell length. This calculated value for $\bar{l}$ of $1.7 \mathrm{~cm}$ is in excellent agreement with the values of brine-cell lengths of $2-3 \mathrm{~cm}$ quoted by Pounder ( $\left[{ }^{\mathrm{c}} \mathrm{I} \mathbf{g}_{6}\right]$ ) and Addison (1969). Certainly it is reassuring that this indirect calculation yields a value which agrees well with the brine cell dimensions obtained from direct petrological measurements. 
THE TEMPERATURE DEPENDENCE OF THE SIZE OF THE BRINE GELLS

We can extend this treatment by making use of the information gained on the three separate traverses across the ice at Pond Inlet. From Table II, $\rho_{1}\left(v_{\mathrm{b}}=40 \%{ }_{0}\right)=104 \Omega \mathrm{m}$, $\rho_{1}\left(v_{\mathrm{b}}=67 \%\right)=80 \Omega \mathrm{m}$, and $\rho_{1}\left(v_{\mathrm{b}}=82 \%\right)=45 \Omega \mathrm{m}$. Recall that each one of these values is an average of 22 soundings. These values for $\rho_{1}$ are plotted as a function of temperature and brine volume in Figure 4, with a smooth curve drawn through to connect the experimental points.

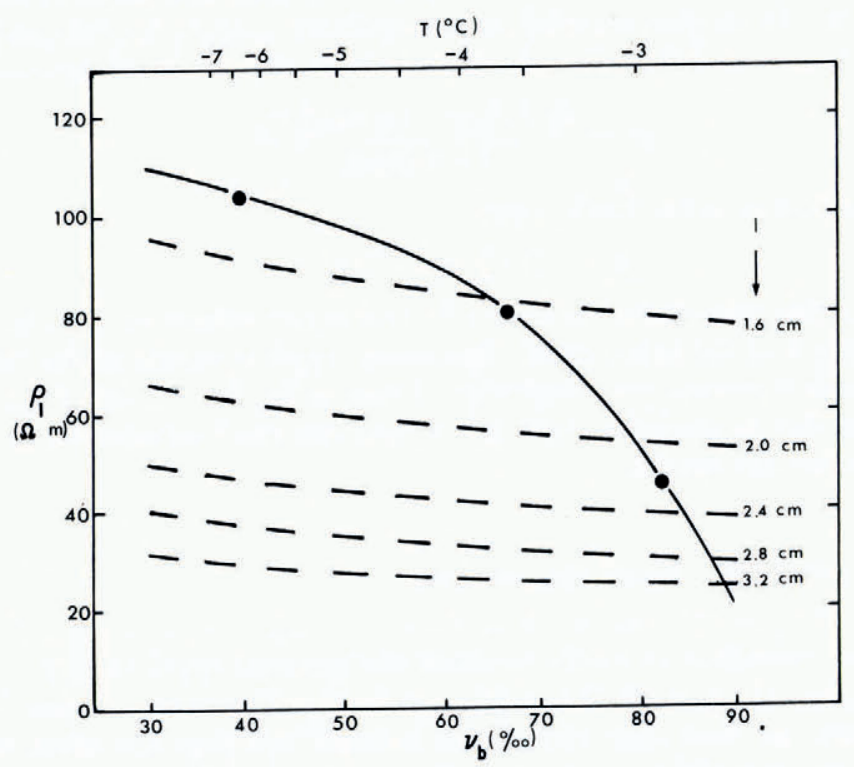

Fig. 4. Graph of resistivity $\rho_{1}$ parallel to the brine-cell direction versus brine volume $v_{\mathrm{b}}$ and temperature T. Solid curve: experimental points each representing 22 soundings; dashed curve: resistivity values calculated from the mixing formula (Equations (Io), (II)) for various "average" brine-cell lengths $l$.

For this calculation, we make the reasonable approximation that in the temperature range $-6.5^{\circ} \mathrm{C}$ to $-3^{\circ} \mathrm{C}$, both $\sigma_{\mathrm{i}}$ and $\sigma_{\mathrm{b}}$ are independent of temperature. Further, we adopt the model of brine volume dependence for the radius $b$ of the brine cells advanced by Anderson (1960), i.e.

$$
b=w\left[\frac{c}{w} \frac{\mathrm{I0}^{-3} v_{\mathrm{b}}}{\pi}\right]^{\frac{1}{2}},
$$

where $w$ is the ice platelet width and $c$ is the average cell spacing along the brine layer. For sea ice, $w$ is approximately $0.046 \mathrm{~cm}$ and $c / w$ is $c .0 .5$ (Anderson, 196o). Using this equation and $\sigma_{\mathbf{i}}=3 \times 10^{-5} \mathrm{~S} / \mathrm{m}$ and $\sigma_{\mathrm{b}}=5 \mathrm{~S} / \mathrm{m}$ in Equations (I0) and (II), we calculate $\rho_{1}$ as a function of brine volume for various constant brine-cell lengths. These are plotted in Figure 4 . In this case for constant $l, \rho_{1}$ is essentially independent of brine volume. Thus, this model suggests that the conductivity parallel to the length of the brine cells changes only slightly if only the widths of the brine cells increase with increasing brine volume. Certainly, this result seems reasonable. Thus, the fact that experimentally $\rho_{1}$ does change with temperature and brine volume (Table II) indicates that the brine-cell lengths do change in this temperature range. Using the intersection points of the curves calculated from the above model and the smooth curve drawn through the experimental $\rho_{1}$ values (Fig. 4), we arrive at the temperature 


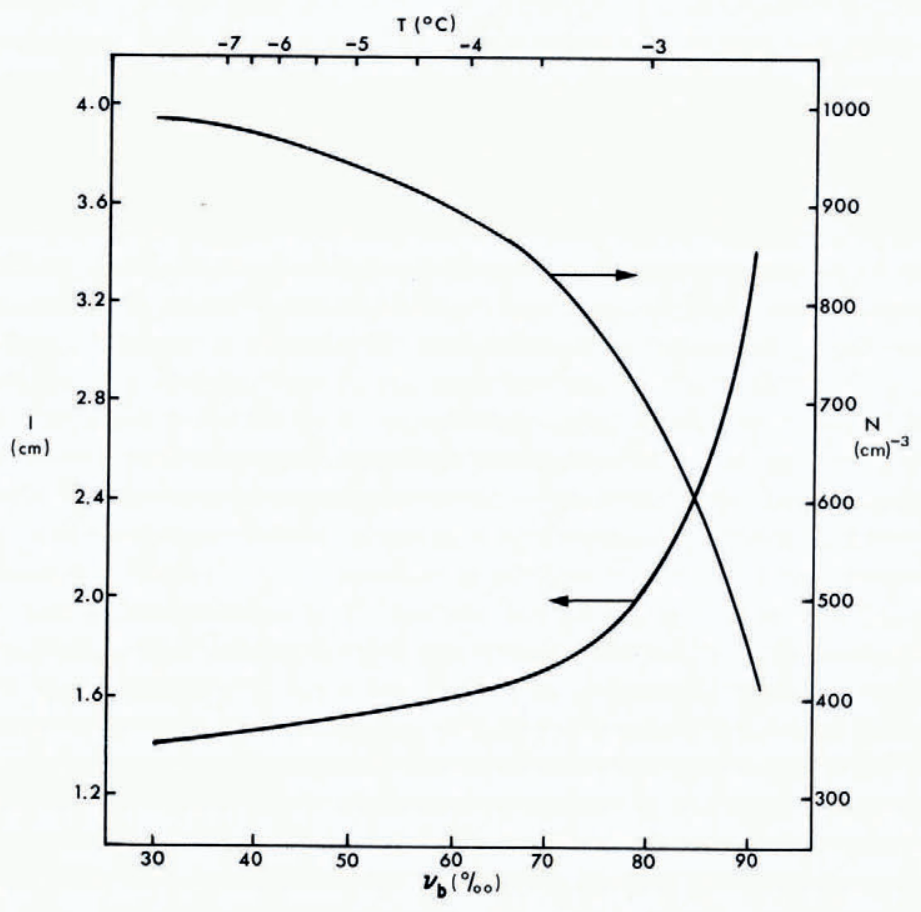

Fig. 5. Graph of "average" brine-cell lengths $l$ and "average" number $\mathcal{N}$ of brine cells versus brine volume $v_{\mathrm{b}}$ and ice temperature $T$.

(or brine volume) dependence of the "average" brine cell lengths as shown in Figure 5. In this case, the results suggest that the brine-cell lengths increase only slightly for $c$. $30 \%<v_{\mathrm{b}}<c .70 \%$ but then rise sharply for $v_{\mathrm{b}}>c .70 \%$. This indicates that the rate of extension of the brine cells is much more rapid for temperatures above $-3 \cdot 5^{\circ} \mathrm{C}$. That is, in this higher temperature region, there is a "runaway" condition of brine-cell enlargement and coalescence to form long continuous brine channels. These channels would lead to the partial desalination of sea ice as discussed by Bennington (1967) and Eide and Martin (1975). Moreover, a calculation of $(\mathrm{I} / l)\left(\Delta l / \Delta v_{\mathrm{b}}\right) /(\mathrm{I} / b)\left(\Delta b / \Delta v_{\mathrm{b}}\right)$ indicates that this ratio is less than one for brine volumes less than $c .70 \%$. This would suggest that for $v_{\mathrm{b}}<c .70 \%$ the relative change in the brine-volume (or temperature) dependence of the brine cells is greater in width than in length. That is, with increasing temperature, the brine cells become more spherical in shape before they increase in length and interconnect to form continuous networks throughout the (warmer) sea ice. This general behaviour agrees qualitatively with that observed from petrological studies of brine cells.

\section{“Average" NUMBER OF BRINE Gells IN SEA IGE}

Using the model of spheroidal-shaped brine cells, we can calculate the temperature dependence of the "average" number $\mathcal{N}$ of brine cells in the sea ice by simply dividing the brine volume fraction of the ice by the volume of an average brine cell, i.e.

$$
\mathcal{N}=\frac{3 \times 10^{-3} v_{\mathrm{b}}}{2 \pi l b^{2}} .
$$

This function is plotted in Figure 5 . In this case, $\mathcal{N} \approx 900(\mathrm{~cm})^{-3}$ for $v_{\mathrm{b}}<c .70 \%$ and drops 
sharply for brine volumes above this value. The sharp drop in the curve simply reflects the fact that the brine cells are much larger and interconnected in this warmer temperature region.

\section{Discussion}

Although the present analysis of the in-situ resistivity of sea ice in terms of its microstructure yields encouraging results, it is clear that since the model employed is highly idealized, the results of such a treatment must be used with reservation. Several refinements and additions would be desirable in order to obtain more detailed and reliable results. Although the data used in this study represent 66 geoelectric soundings of 22 each over three different ice temperatures, more data of this nature over a wider range of ice temperatures would be invaluable. In addition, Schlumberger profiles on a vertical wall of sea ice for each temperature sampled would yield important information on the functional dependence of $\lambda$ on temperature. Refinements to the model include incorporating a statistical variation in the size of the brine cells, and noting that the geometry of the brine cells change from long, thin needles at the colder temperatures to conducting discs for very warm temperatures (close to melting). The latter is easily accomplished by choosing a model of conducting ellipsoids for the brine cells. Further, if a great deal of experimental data were available, it would be worthwhile to try to refine the value for $\sigma_{i}$ and to consider the relatively small temperature dependence of both $\sigma_{\mathrm{b}}$ and $\sigma_{\mathrm{i}}$ in this temperature region.

In this first attempt at calculating average brine cell lengths from the in-situ resistivity data for sea ice, the results are encouraging. The calculated value for an average brine cell length in sea ice of $1.7 \mathrm{~cm}$ is in good agreement with that observed petrologically. Moreover, the derived temperature dependence of the shape and geometry of the brine cells agrees at least qualitatively with direct petrological observations. Since this aspect of sea ice is understandably complex, petrological studies have not determined the quantitative changes in brine-cell length with temperature." As such, the present treatment of interpreting the d.c. resistivity of sea ice in terms of its microstructure yields a useful method for evaluating these changes.

\section{Acknowledgements}

The author would like to thank Drs C. R. Bentley, H. H. Schloessin, and E. Whalley for several helpful comments on the manuscript.

MS. received 30 March 1978 and in revised form 10 October 1978

\section{REFERENCES}

Addison, J. R. 1969. Electrical properties of saline ice. Fournal of Applied Physics, Vol. 40, No. 8, p. 3105-14. Anderson, D. L. 1958. A model for determining sea ice properties. (In Arctic sea ice. Washington, D.C., p. 148-52. (National Academy of Sciences-National Research Council Publication 598.))

Anderson, D. L. 1960. The physical constants of sea ice. Research, Vol. 13, No. 8, p. $310-18$.

Assur, A. 1958. Composition of sea ice and its tensile strength. (In Arctic sea ice. Washington, D. C., p. $106-38$. (National Academy of Sciences-National Research Council Publication 598.))

Beek, L. K. H. van. 1967. Dielectric behaviour of heterogeneous systems. Progress in Dielectrics, Vol. 7, p. 69-1 14. Bennington, K. O. 1967 . Desalination features in natural sea ice. Fournal of Glaciology, Vol. 6, No. 48, p. 845-57. Bhattacharya, P. K., and Patra, H. P. I 968 . Direct current geoelectric sounding; principles and interpretation. Amsterdam, etc., Elsevier Publishing Co. (Methods in Geochemistry and Geophysics, 9.)

Campbell, K. J., and Orange, A. S. 1974. The electrical anisotropy of sea ice in the horizontal plane. Journal of Geophysical Research, Vol. 79, No. 33, p. 5059-63.

Cowan, V. M., and others. Unpublished. The dc resistivity of sea ice, by V. M. Cowan, G. W. Timco, H. Kohnen, and F. Thyssen. Canadian Arctic Channel Project. Ice Physics Report. Brock University, St Catharines, Ontario, Canada. [Written 1972.] 
Dichtel, W. J., and Lundquist, G. A. 1951. An investigation into the physical and electrical characteristics of sea ice. Bulletin of the National Research Council of the U.S., No. 122, p. 122.

Eide, L. I., and Martin, S. 1975. The formation of brine drainage features in young sea ice. Fournal of Glaciology, Vol. 14 , No. 70, p. 137-54.

Frankenstein, G. E., and Garner, R. 1967. Equations for determining the brine volume of sea ice from -0.5 to $-22.9^{\circ} \mathrm{C}$. Journal of Glaciology, Vol. 6, No. 48 , p. $943-44$.

Fricke, H. 1924. A mathematical treatment of the electric conductivity and capacity of disperse systems. I. The electric conductivity of a suspension of homogeneous spheroids. Physical Review, Ser. 2, Vol. 24, No. 5, p. $575^{-87}$.

Gow, A. J., and Weeks, W. F. 1977. The internal structure of fast ice near Narwhal Island, Beaufort Sea, Alaska. CRREL Report 77-29.

Hillig, W. B. 1958. The kinetics of freezing ice in the direction perpendicular to the basal plane. (In Doremus, R. H., and others, ed. Growth and perfection of crystals. Proceedings of an international conference on crystal growth, held at Cooperstown, New York, Aug. 27-29, 1958. Edited by R. H. Doremus, B. W. Roberts, D. Turnbull. New York, John Wiley and Sons, Inc., p. 350-6o.)

Hoekstra, P., and Cappillino, P. 197I. Dielectric properties of sea and sodium chloride ice at UHF and microwave frequencies. Journal of Geophysical Research, Vol. 76, No. 20, p. 4922-31.

Keller, G. V., and Frischknecht, F. C. 1966. Electrical methods in geophysical prospecting. Oxford, Pergamon Press. (International Series of Monographs in Electromagnetic Waves, Io.)

Kohnen, H. [1976.] On the dc-resistivity of sea ice. Zeitschrift für Gletscherkunde und Glazialgeologie, Bd. I I, Ht. 2, I 975 , p. 143-54.

Pounder, E. R. [ $\left.{ }^{\mathrm{c}} 1965.\right]$ The physics of ice. Oxford, etc., Pergamon Press. (The Commonwealth and International Library. Geophysics Division.)

Pounder, E. R., and Little, E. M. 1959. Some physical properties of sea ice. I. Canadian Fournal of Physics, Vol. 37, No. 4, p. $443-73$.

Thyssen, F., and others. 1974 . DC resistivity measurements on the sea ice near Pond Inlet, N.W.T. (Baffin Island), by F. Thyssen, H. Kohnen, [V. M.] Cowan, and G. W. Timco. Polarforschung, Jahrg. 44, Nr. 2, p. I 1 7-26.

Weeks, W. F., and Assur, A. I963. Structural control of the vertical variation of the strength of sea and salt ice. (In Kingery, W. D., ed. Ice and snow; properties, processes, and applications: proceedings of a conference held at the Massachusetts Institute of Technology, February 12-16, 1962. Cambridge, Mass., M.I.T. Press, p. 258-76.)

Weeks, W. F., and Assur, A. 1968. The mechanical properties of sea ice. Canada. National Research Council. Associate Committee on Geotechnical Research. Technical Memorandum No. 92, p. 25-78.

Weeks, W. F., and Hamilton, W. L. 1962. Petrographic characteristics of young sea ice, Point Barrow, Alaska. U.S. Cold Regions Research and Engineering Laboratory. Research Report 101. 